
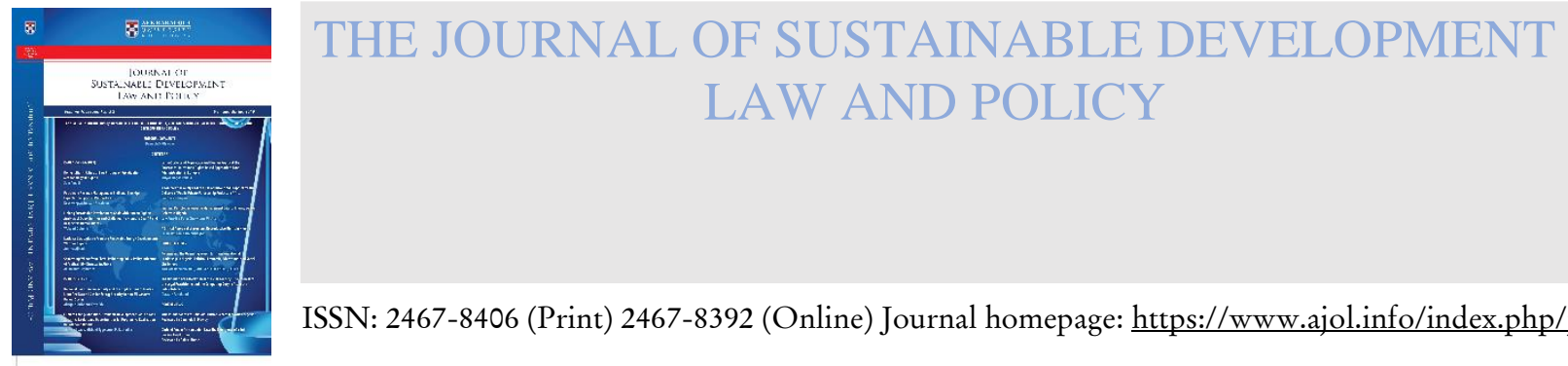

ISSN: 2467-8406 (Print) 2467-8392 (Online) Journal homepage: https://www.ajol.info/index.php/jsdlp

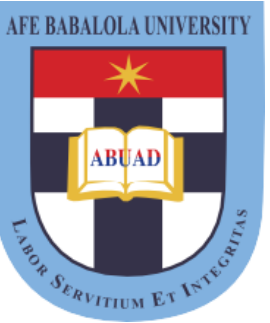

\title{
The Political Prohibition Clause of the World Bank Charter and the Legal Implications for the Fight against Corruption in Africa
}

\section{Franck Maxime Yankam Lemdjo}

To cite this article: Franck Maxime Yankam Lemdjo (2020) The Political Prohibition Clause of the World Bank Charter and the Legal Implications for the Fight against Corruption in Africa, The Journal of Sustainable Development, Law and Policy, 11:2, 382-406,

To link to this article: https://dx.doi.org/10.4314/jsdlp.v11i2.5

Full Terms \& Conditions of access and use can be found at https://www.ajol.info/index.php/jsdlp 


\title{
The Political Prohibition Clause of the World Bank Charter and the Legal Implications for the Fight against Corruption in Africa
}

\author{
Franck Maxime Yankam Lemdjo* \\ (Received 21June 2020; final version received 12 October 2020)
}

Article 4(10) of the World Bank Articles of Agreements (hereafter referred the World Bank Charter) adopted in 1944 prohibits World Bank staff from taking political factors into account in their operations and loans decisions for projects of development. Article 4(10) has been at the heart of a sound debate that is reviewed in this paper in relation to human rights and corruption. The discussion is a step further of the colloquium referred as the "Justice and Development Week" organised in November 2010 by the World Bank Legal Vice Presidency Law held in Washington- USA. The purpose of that international meeting was to examine the political prohibition clause in International Development Finance. One of the issues raised during the seminar was the interpretation of the World Bank Charter particularly its Article 4(10).

This article discusses the matter and focuses mainly on major issues of the political clause: First, the historical reasons of the insertion of the political prohibition clause in the World Bank Charter and the arguments in support of as well as in opposition to such a restrictive approach by the Bank to engaging with corruption and human rights issues. Second, an analytical discussion of the Bank's economic perspective and exclusive definition to corruption followed by the legal discrepancies of such a regime of sanctions in comparison with those set by $\mathrm{UN}$ and $\mathrm{AU}$ anti-corruption conventions.

Keywords: International Agencies, Articles of Agreement, Political prohibition clause, Fight against Corruption.

\section{INTRODUCTION}

careful examination of the World Bank Group's purpose
shows as a general rule, a deep interest for that organisation to remain a key International Financial Institution (IFI). ${ }^{1}$ Established in 1944 after the World War II, the aim of the World Bank ${ }^{2}$ was to help finance the

* LL.B, LL.M, PhD Fellow.

1 The World Bank Group includes the International Bank for Reconstruction and Development (IBRD); the International Development Asso -ciation (IDA); the International Finance Corporation (IFC); the Multilateral Investment Guarantee Agency (MIGA); and the International Centre for Settlement of Investment Disputes (ICSID).

2 The World Bank is composed by two organisations: The International Bank for Reconstruction and Development (IBRD) and the International Development Association (IDA). 
reconstruction of Europe and the economic development of its erstwhile colonies and a few independent states in Africa, Asia, and Latin America. ${ }^{3}$ With 189 Member States today, the World Bank is still working to achieve the purpose ${ }^{4}$ of: assisting countries, promoting foreign investments and growth, arranging loans and conducting its operations so as to generate productivity ${ }^{5}$ within these countries. The World Bank Charter also referred as Articles of Agreements, further stipulates that, in less developed countries, the Bank's purpose is "to [encourage] the development of productive facilities and resources". ${ }^{6}$ In order to achieve these objectives, there are some guiding principles that have been defined in the Articles of Agreements so as to direct the decisions of the Bank operating within the realm of those goals set by Article 1. In this perspective, and as one of the strongest principles, the Bank's Charter [obliges the Bank staff to consider merely economic factors in their decisions] prohibits Bank staff from interfering in the political affairs of its Members States and from taking political considerations into account in its operations.

That principle, the so-called political prohibition clause, is primarily defined in Article IV Section 10 of the World Bank Charter. It literally states that: "the Bank and its officers shall not interfere in the political affairs of any member; nor shall they be influenced in their decisions by the political character of the member or members concerned.

Only economic considerations shall be relevant to their decisions, and these considerations shall be weighed impartially in order to achieve the purposes stated in Article $1 "$ ?

3 IBRD Articles of Agreement, Article I, available at: https://www.wor ldbank.org/en/about/articles-of-agreement/ibrd-articles-of agreement.

4 Article 1 of the International Bank for Reconstruction and Development (IBRD) Charter.

5 The words "productivity", "productive facilities", "productive purposes" and "productive resources" appear several times in the first article of the IBRD Charter.

6 Article 1 (i) of the International Bank for Reconstruction and Develop -ment (IBRD) Charter.

7 This provision of Article IV Section 10 is accentuated by Article III, se -ction 5(b) of the IBRD Articles of Agreement which provides equally that "the Bank's loan proceeds must be used only for their intended pu -rposes and "with due attention" to economy "without regard to politi- 
This article addresses the legal implications of the implementation of Article 4(10) of the World Bank Charter. It discusses the matter and focuses mainly on major issues of the political clause with respect to the fight against corruption in particular. After this introduction, section 2 exposes the historical reasons of the insertion of the political prohibition clause in the 1944 World Bank Charter and the arguments in support of as well as those advanced in opposition to such a restrictive approach by the Bank in dealing with corruption and/or human rights issues. Section 3 provides an analytical discussion of the Bank's exclusive economic perspective and inadequate definition of corruption. This is followed by the legal discrepancies of the Bank's regime of sanctions against corruption in comparison with those set namely by UN and AU anti-corruption conventions. Section 4 provides some recommendations on how to address the negative effects of Article 4(10) of the World Bank Charter. Section 5 is the concluding section.

\section{THE HISTORICAL REASONS FOR ARTICLE 4(10) OF THE WORLD BANK CHARTER}

Before engaging the discussions and problems raised by the political prohibition clause of the World Bank operations in light of achieving its purposes, it is important to recall on one hand, the historical background of this specific legal provision by revisiting the reasons behind the drafting of such a prohibition in the Bank's Charter. Also, it will also be important to analyse and understand, the arguments against such a provision related to the Bank's operations. The World Bank Charter was drafted and adopted in 1944. The founders of the Bank were factually influenced by the political, economic, philosophical, and geopolitical environment that prevailed at that specific time. Hence, they wanted the World Bank to be efficient and serve the purposes attached to its creation. The major sequential arguments in support of the Bank's political prohibition clause are as follows:

cal or other non-economic influences or considerations". 


\subsection{The idea that political prohibition provides the Bank more efficiency as a result of the confidence it has in the advantages of capitalism}

The confidence in capitalism is referred as one of the strongest reasons to justify the importance of the political prohibition clause within the Bank. This is based on the asserted fact that the economic performance of a State does not automatically depend on its democratic status. In this line, the Bank has always believed that economic freedom is the solution for its expansion and efficiency as an International Financial Institution. Generally, the Bank has focused exclusively on the economic dimensions of development, operating in a globalised capitalist market.

According to Hassan Cisse ${ }^{8}$, the former deputy general counsel of the World Bank, the historical point about the confidence of the Bank in capitalism is taken from the speech of Lord Keynes at the Inaugural Meeting of the Bank and the Fund at Savannah (1946), where he stated that "if these institutions are to win the full confidence of the suspicious world, it must not only be, but appear, that their approach to every problem is absolutely objective and ecumenical without prejudice or favour".

As a result of this approach, the Bank has been able to remain one of the largest development financial institutions, providing technical assistance in developing countries and around the world. In fiscal year 2019 for example, the IBRD committed \$23.6 billion and IDA committed 21.9 billion dollar for 351 new operations. ${ }^{10}$ The World Bank has redefined its mission in two goals: reducing the share of the global population that lives in extreme poverty to three percent by 2030 and increasing the incomes of the poorest 40

$8 \quad$ Hassan Cisse, 'Navigating the Muddy Waters of Politics in International Development Finance - Should the Political Prohibition in Charters of International Financial Institutions be revisited? The case of the World Bank', [2010] in report of The World Bank Legal Vice Presidency Law, Justice and Development Week, 9th November 2010; siteresources .worldbank.org/INTLAWJUSTICE/.../HCissePresensentation_ Nov7.ppt

9 As above.

10 Available at: https://www.worldbank.org/en/about/annual-report (accessed 24/10/2019). 
per cent of people in every country. The World Bank loans and grants money for financial assistance worldwide. As from October 2018, the Bank's website indicated that the amount of $\$ 45.9$ B was spent for 12,000 projects to support development and relief in 189 member countries. ${ }^{11}$

The World Bank Group comprises five institutions managed by their member countries. It provides low-interest loans, zero to low-interest credits, and grants to developing countries. By doing so, it supports a wide array of investments in such areas as education, health, public administration, infrastructure, financial and private sector development, agriculture, environmental and natural resource management. Some of its projects are co-financed with governments, others with multilateral institutions, commercial banks, export credit agencies, and private sector investors.

\subsection{The idea that the political prohibition prevents the} Bank from being an institution settling political disputes among its Member States

This argument is also provided to justify the inclusion of Article 4 section 10 of the Bank Articles of Agreement. Hence, although the Bank is considered as a specialised agency of the United Nations, the political prohibition clause has been the basis under which the Bank has shaped certain issues such as human rights from its mandate. In this line, the Bank has generally been reluctant to fully consider human rights as promoted and protected by the UN as part of its own mandate. For instance, the Bank had carefully declined the invitation to take part in the drafting of the UN Convention on Economic Social and Cultural Rights in 1966. Similarly, the Bank had refused to follow the instructions of the UN Security Council to withhold assistance to the South African Apartheid Regime for its human rights violations ${ }^{12}$ as well as

11 As above.

12 See UN Doc A/AC09/124 (10 June1984), s.116. See also, 'The Policies of Apartheid of the Government of the Republic of South Africa' G.A. Res. 2054, U.N. GAOR, 20th Sess., Supp. No. 14, at 16, U.N. Doc.A/6014 (1966) (recommending that economic sanctions be applied against South Africa due to its government's continuation of its apartheid policies). 
Portugal, in 1977, for its rigorous treatment against its former colonies. ${ }^{13}$

For Hassan Cisse, this argument is taken from a paper prepared by the US Treasury in early 1944. That document explained the World Bank draft Articles of Agreement and addressed the issue of the political prohibition. Following this broadsheet, the "political activities" are prohibited for the reason that the Bank did not want to be an institution for the settlement of political disputes with its Members. Hence, this restrictive approach has prevented the Bank to be an institution settling political disputes or using its loans as an instrument of political negotiation or pressure on States. Similarly, the Bank has continually argued that its work in non-democratic countries was vital because its mission was to help the poor regardless of the regime, and the 'worst' countries might have found it difficult to find funding elsewhere. ${ }^{14}$

\subsection{The idea that the political prohibition enables the Bank to function as an Impartial IFI, which has corporate structure and acts as a financial intermediary as it was designed for}

The need to separate the Bank from all kinds of political activities further emerged after the cold war between capitalist and communist countries. At the time of the Cold War, both the United States of America and Union Soviet Socialist Republic tried to obtain the dependability of developing nations through assistance, and recipients often held a degree of power in these negotiations. Fearing that rejected states would turn instead to communist countries for aid, the West propped up several totalitarian regimes in order to stabilise the political climate. Some more notorious examples include Chile under Pinochet, the Philippines under Marcos, Uganda under

${ }^{13}$ G.A. Res. 2105, U.N. GAOR, 20th Sess., Supp. No. 14, at 4, U.N. Doc. A/6014 (1965) on the implementation of the Declaration on the Granting of Independence to Colonial Countries and Peoples, (requesting that all international institutions withhold assistance from the governments of Portugal and South Africa until they reverse their policies of racial discrimination and colonial domination).

14 R Ayres, Banking On The Poor: The World Bank and World Poverty (The MIT Press, 1983) 56. 
Amin, Equatorial Guinea under Macias, and perhaps most famously, Zaire under Mobutu. ${ }^{15}$

It was not only this unique political climate that encouraged both bilateral and multilateral donors to support authoritarian regimes. At the time, it was presumably evident that there were too many totalitarian regimes that were said to have greater economic performances than some "democratic" countries that faced severe economic challenges. Hence, the Bank decided to collaborate with countries that were considered as authoritarian.

As the norm, rather than the exception, it is argued by the Bank that, donors were unlikely to take the nature of a political regime into account when distributing aid. If they did, there would indeed be few recipients to take advantage of aid. ${ }^{16}$ That is why, "the mandate of the Bank was designed to protect its reputation as a conservative, technocratic financial institution" ${ }^{31}$ The impartiality of the Bank appeared to be one of its strongest values, which is the reason why in a nutshell, "political considerations [were] supposed to be irrelevant... especially as the Bank's credibility and strength has traditionally depended on its status as a quintessential technocracy exclusively concerned with economic efficiency." 17

\section{THE DEBATES SURROUNDING THE POLITICAL PROHIBITION CLAUSE OF THE BANK OPERATIONS}

One of the latest/rarest attempts by the Bank to provide clarification on the political prohibition clause was the "Justice and Development Week" organised in November 2010 by the World Bank Legal Vice Presidency Law. The purpose of that colloquium was to re-examine and address the issue of the political prohibition clause in International Development Finance and on human rights.

15 A Hoogvelt 'Globalisation and the Post-Colonial World: The New Political Economy of Development' (1997) 172

16 M Heather 'The origins and development of the world bank's anticorruption programme' [2002] PhD thesis, Durham University, Department of Politics, 21; I Shihata 'The World Bank in a Changing World' [2000] 165.

17 S George \& F Sabelli 'Faith and Credit: The World Bank's Secular Empire' (1994) 50. See also, I Shihata 'The World Bank in a Changing World: Selected Essays' (1991) 10. 
Some of the areas in which the political prohibition clause of the Bank has been challenged relates to the Bank relations with de facto Governments, the question of treatment of human rights; the Bank's involvement in the security sector or criminal justice reform and the Stolen Asset Recovery Initiative. In order to achieve this objective, the Bank has to reconsider its restrictive approach and rather enter into new proactive ones with clear oversight and accountability mechanisms of its operations. Hence, it is important to note in this line that, over the course of its existence, the Bank has established several accountability and review entities with oversight over Bank operations and affairs. Unlike the Board of Directors or the President, these entities do not owe their existence to the Articles. In fact, the Articles are completely silent about them. Some of these entities were created under the President's power to conduct the Bank's ordinary business ${ }^{18}$, while others were established under the Bank's implied powers.

Some entities, notably the Administrative Tribunal, were established by the Board of Governors. Others, such as the Inspection Panel and the Sanctions Board, were created through Executive Directors' resolutions or other decisions. Still others, like the Internal Audit Department or the Independent Evaluation Group, owe their existence to specific Management actions. However, despite improvement of the Bank operations with respect of human rights namely through the adoption of new operational policies ${ }^{19}$ as well as by establishing Expert Advisory Panels, the Bank engagements against corruption remain insufficient.

Although the Bank has recently adopted policies and procedures against corruption, these policies are still quite

18 IBRD Articles, Article V, Section 5 (b) and IDA Articles, Article VI, Section 5 (b).

19 Bank policies and procedures include inter alia the following: the Environmental Assessment (O.D 4.01), Involuntary Resettlement (OD 4 .15), Natural Habitats (OP/BP 4.04), Pest Management (OP.4.09), Po -verty Reduction (O.D 4.15, Indigenous Peoples (OD 4.20), Forestry (OP 4.36), Disclosure of Operational Information (BP 17.50), Economic Evaluation of Investment Operations (OP 10.04), Project Monitoring and Evaluation (OD 10.70), Project Supervision (OD 13.05), and Management of Cultural Property in Bank financed projects (OPN 11.03). 
below the anti-corruption standards defined by African Union Convention on preventing and combating corruption as well as the United Nations Convention against corruption. The difference of standards between the Bank's anticorruption policies and regional and international anticorruption conventions can be perceived at the level of both the definition and criminalisation of corruption.

\subsection{An economic rather than a political definition of corruption}

Most definitions relate corruption to the behaviour of a public official, who may be the object or the subject of corruption. Thus corruption is "an illegal payment to a public agent to obtain a benefit that may or may not be deserved in the absence of payoffs" or "the sale by government officials of government property for personal gain". ${ }^{20}$ The benefit may not be financial or immediate, the public official may be appointed or elected, and the bribe may be offered or extorted.

The Bank's economic definition of corruption was earlier given by its former President Wolfensohn who said that the Bank decided to redefine the word corruption, regarding it as an economic, rather than a political matter. The Bank's position also has been around the idea that almost all human rights have economic implications and most economic issues involve a series of political calculations and considerations. Shihata had defined issues related to "the art and practice of running a country or governing," as "political", but he excludes "such typical economic and technical issues such as the 'management of money or the finances or more generally the efficient management of the countries' resources. ${ }^{21}$ For Shihata, "the issues at hand is simply to identify aspects of governance that are relevant to the Bank's work and may therefore defensibly fall within its mandate, and aspects that

20 A Shleifer \& RW Vishny, 'Corruption' [1993], The Quarterly Journal of Economics, 599-617.

21 Martha Heather 'The origins and development of the world bank's anticorruption programme' [2002], PhD thesis, Durham University, Department of Politics. 
are clearly political considerations, which cannot be taken into account without breaching the Bank's Articles [of Agreement]. Such identification will make it possible for the Bank to determine the governance issues it may formally take up in its dialogue with borrowing countries and appropriately address in its operations, and the issues it should ignore in its work". ${ }^{22}$

The current World Bank policies and procedures on corruption, which evidently set an economic approach to corruption are:

i. The Bank Directive: Sanctions for Fraud and Corruption in Bank Financed Projects, ${ }^{23}$

ii. The Anti-corruption guidelines for World Bank guarantee and Carbon finance transaction, ${ }^{24}$

iii. The Bank Guidelines on preventing and combating fraud and corruption in program for results financing, ${ }^{25}$

iv. The Bank Directive: Guidelines on Preventing and Combating Fraud and Corruption in Projects Financed by IBRD Loans and IDA Credits and Grants (revised as of July 1, 2016), ${ }^{26}$

v. The World Bank Group Policy: Sanctions for Fraud and Corruption, ${ }^{27}$

vi. The Guidelines on Preventing and Combating Fraud and Corruption in Projects Financed by IBRD Loans and IDA Credits and Grants (revised as of July 1, 2016). ${ }^{28}$

The assessment of these Bank anti-corruption policies and procedures, which are all influenced by the Bank "organizational myth." 29 If compared with the standards set

${ }^{22}$ See Ibrahim Shihata 'the World Bank and Human Rights: An Analysis of the Legal Issues and the Record of Achievements' (1988) 46-47 Denver Journal of International Law and Politics.

23 https://policies.worldbank.org/sites/ppf3/PPFDocuments/Forms/DispPage.aspx?docid=3871 (accessed on October $\left.3^{\text {rd }}, 2018\right)$.

24 https://policies.worldbank.org/sites/ppf3/PPFDocuments/Forms/Dispage.aspx?docid=1971 (accessed on October $\left.3^{\text {rd }}, 2018\right)$.

25 Ibid.

${ }^{26}$ Ibid.

${ }^{27}$ Ibid.

28 Ibid.

29 Martha Heather 'The Origins and Development of the World Bank's Anti Corruption Programme' [2002] PhD Thesis, (83), Durham University, 
by the AU and UN Conventions against corruption, it is clear that the Bank definition of corruption is a minimalist one and merely based on economic considerations.

In this line and as an example, the Bank's Procurement Guidelines take a functional perspective, defining a corrupt practice as "the offering, giving, receiving, or soliciting of anything of value to influence the action of a public official in the procurement process or in contract execution."

Similarly, the World Bank Guidelines on preventing and combating fraud and corruption in program for resultsfinancing address Fraud and Corruption that may occur in connection with the preparation and implementation of programs financed, in whole or in part, by the IBRD or the IDA through Program-for-Results Financing. They set out the general principles, requirements, and sanctions applicable to such programs. Nonetheless, following these Guidelines, it is clear that the Bank has an exclusive economic rather than political understanding of corruption. The Guidelines state that: " $[\mathrm{t}]$ he Loan Agreement ${ }^{30}$ providing for the Loan ${ }^{31}$ governs the legal relationships between the Borrower ${ }^{32}$ and the Bank $^{33}$ with respect to the Program ${ }^{34}$ for which the Loan is made. The responsibility for the implementation of the Program under the Loan Agreement, including the primary responsibility for preventing and combating Fraud and Corruption, rests with the Borrower. "The Bank, for its part,

Department of Politics.

${ }^{30}$ References in the Guidelines to "Loan Agreement" include any Loan Agreement providing for an IBRD loan; Financing Agreement providing for an IDA credit or IDA grant; Trust Fund Grant Agreement or Loan Agreement providing for a recipient-executed trust fund grant or loan in cases where these Guidelines are made applicable to such agreement; and the Program Agreement with a Program Implementing Entity related to any of the above.

${ }^{31}$ References to "Loan" or "Loans" include IBRD loans as well as IDA credits and grants, project preparation advances, and recipient-executed tru -st fund grants or loans for programs to which these Guidelines are made applicable under the agreement providing for such grant and/or loan. These Guidelines do not apply to investment project financing (to which separate guidelines apply) or to development policy financing-

32 References in the Guidelines to "Borrower" include the recipient of an IDA credit or grant or of a trust fund grant or loan.

33 References in the Guidelines to the "Bank" include both IBRD and IDA.

34 Reference in the Guidelines to the "Program" means the Program as defined in the Loan Agreement. 
has a fiduciary duty under its Articles of Agreement to make arrangements to ensure that the proceeds of any loan are used only for the purposes for which the loan was granted, with due attention to considerations of economy and efficiency and without regard to political or other non-economic influences or considerations." ${ }^{35}$ These Guidelines constitute an important element of those arrangements and are made applicable to the preparation and implementation of the Program as provided in the Loan Agreement." 36

In the same perspective, other Bank policies on corruption provide additional definitions of practices constituting fraud and corruption. The Guidelines on preventing and combating fraud and corruption in program for results-financing define exclusive economic related practices with no reference to political or human rights dimensions of corruption. The practice defined by the World Bank policies is specifically: a "corrupt practice". ${ }^{37}$ According to the Guidelines, typical examples of corrupt practices include bribery and "kickbacks", a "fraudulent practice" 38 , a "collusive practice" 39 , a "coercive practice" 40 and an "obstructive practice" 41 as

35 Emphasis added. IBRD Articles of Agreement, Article III, Section 5(b); IDA Articles of Agreement, Article V, Section 1(g).

36 World Bank Guidelines on preventing and combating fraud and corruption in program for results-financing, para $2{ }^{65}$ The World Bank, Helping Countries Combat Corruption: The Role of the World Bank, available at: http://www1.worldbank.org/publicsector/anticorrupt/corruptn/cor02.htm

37 A "corrupt practice" is defined as the offering, giving, receiving, or soliciting, directly or indirectly, of anything of value to influence improperly the actions of another party.

38 A "fraudulent practice" is defined as any act or omission, including a misrepresentation, that knowingly or recklessly misleads, or attempts to mislead, a party to obtain a financial or other benefit or to avoid an obligation.

39 A "collusive practice" is defined as an arrangement between two or more parties designed to achieve an improper purpose, including to influence improperly the actions of another party.

40 A "coercive practice" is defined as impairing or harming, or threateni-ng to impair or harm, directly or indirectly, any party or the property of the party to influence improperly the actions of a party.

41 An "obstructive practice" is defined as (i) deliberately destroying, falsifying, altering or concealing of evidence material to the investigation or making false statements to investigators in order to materially impede a Bank investigation into allegations of a corrupt, fraudulent, coercive, or 
practices only understood of constituting fraud and corruption within the Bank operations.

The Anti-corruption guidelines for the World Bank guarantee and Carbon finance transaction provide the interpretation of each of the five prohibited practices of corruption. Among the five interpretations provided by the Bank, there are at least two interpretative issues to be addressed. First, following the Bank guidelines, Corrupt Practices are understood as "kickbacks and bribery. The conduct in question must involve the use of improper means (such as bribery) to violate or derogate a duty owed by the recipient in order for the payor to obtain an undue advantage or to avoid an obligation". ${ }^{42}$ The problem with this definition of Corrupt Practices is that the Guidelines provide an openended and unclear exception which is that "antitrust, securities and other violations of law that are not of this nature are excluded from the definition of Corrupt Practices". ${ }^{43}$ This provision of "other violations of law that are not of this nature" basis of the exclusion of behaviours and actions excluded from the scope of the Bank's definition of corruption needs to be clarified. The reason is the fact that the Guidelines have been drafted very explicitly so as to capture all reasonable practices to be considered as corruption. Equally, this provision is contracting with the legal principle requiring that one cannot be punished for doing something that is not prohibited by law known as nulla poena sine lege. ${ }^{44}$

Secondly, the Bank guidelines further precise that "fraudulent practices are intended to cover acts or omissions that are directed to or against a World Bank Group entity. It also covers Fraudulent Practices directed to or against a World Bank Group member country in connection with the award or implementation of a government contract or concession in a project financed by the World Bank Group. Frauds on other third parties are not condoned but are not specifically

collusive practice; and/or threatening, harassing or intimidating any party to prevent it from disclosing its knowledge of matters relevant to the investigation or from pursuing the investigation, or (ii) acts intended to materially impede the exercise of the Bank's contractual rights of audit or access to information.

42 Anti-corruption guidelines for World Bank guarantee and Carbon finance transaction, para 1 .

43 As above.

44 Latin expression for "no penalty without a law" 
sanctioned in World Bank guarantee projects or carbon finance operations".

The problem arises as the Bank Guidelines further state that, "other illegal behaviour is not condoned, but will not be sanctioned as a Fraudulent Practice under the World Bank sanctions program as applicable to World Bank guarantee projects or carbon finance operations" ${ }^{45}$ This provision is tantamount to nullifying attempts to address corrupt practices by the Bank. The Guidelines would have rather provided for a provision that encompasses all possible practices of similar nature as fraudulent practices instead of narrowing the possibility of qualifying and therefore sanctioning 'other illegal behaviour' that are not 'condoned but will not be sanctioned".

\subsection{Anti-corruption standards of the African Union and the United Nations}

However, it is inadequate to address corruption in Africa without linking it to political issues. Political scientists look beyond the visible signs of corruption to the broader setting in which it occurs. ${ }^{6}$ They see corruption in relation to the legitimacy of the State, the patterns of political power, and the engagement of civil society. Equally, as we argue, both the United Nations and African Union Conventions against corruption put an emphasis on the relevance of political aspects of combatting corruption and both give importance to the role of civil society to fight corruption.

Corruption may also be a manifestation of the way political power is contested and exercised. Likewise, it is conceivably linked to the leadership, to the way the creation and allocation of State rents serves political purposes: such as rewarding supporters, buying off opponents, ensuring the backing of key groups, managing ethnic diversity, or simply accumulating resources to fight elections. To obtain these resources, leaders may forge alliances with business groups or create and distribute rents through the bureaucratic apparatus. The resulting policies may favour or discourage capital accumulation and economic growth, depending on the nature

45 Anti-corruption guidelines for World Bank guarantee and Carbon finance transaction, para 1 a. 
of the alliances struck. Politicians in such countries may be aware of the distortionary consequences of such rents but view them as a necessary tool of political management. If this is the case, the pattern of corruption will change only if the power structure changes, which may result from a popular outcry against corruption. Over time most industrial countries have developed merit-based bureaucratic values, institutionalized competitive politics, established transparent government processes, and fostered an active media and an informed civil society. These mechanisms constrain political and bureaucratic corruption, making it the exception rather than the norm.

In developing countries, in contrast, government institutions are weaker, civil society is less engaged, and political and bureaucratic processes are less accountable and transparent. An effective state apparatus and capacity for law enforcement may be virtually non-existent. In such settings, sustained progress in building an honest and effective state apparatus requires addressing the mix of factors in the state and in society that give rise to both corruption and weak social and economic performance. This is an exceedingly complex and long-term effort. ${ }^{46}$

The Bank exclusive economic approach to corruption is not fully in line with the African Union Convention on preventing and combating corruption. The objectives of the Convention are to "promote and strengthen the development in Africa by each State party of mechanisms required to prevent, detect, punish and eradicate corruption and related offences in the public and private sectors". ${ }^{47}$ The principles of the Convention set as follows: "States parties to [the] Convention undertake to abide by the following principles: 1 . respect for democratic principles and institutions, popular participation the rule of law and good governance; 2. respect for human and peoples' rights in accordance with the African Charter on Human and Peoples' Rights and other relevant human rights instruments; 3 . transparency and accountability in the management of public affairs; 4. the promotion of social justice to ensure balanced socio-economic development; 5 .

46 The World Bank, Helping Countries Combat Corruption: The Role of the World Bank, available at: http://www1.worldbank.org/publicsec tor/anticorrupt/corruptn/cor02.htm (accessed 1 May 2018).

${ }^{67}$ See article 2 of the Convention. 
condemnation and rejection of acts of corruption, related offences and impunity". ${ }^{48}$

The African Union Convention puts a strong emphasis on the role of civil society in combatting corruption. The preamble of the Convention states that: "[d]etermined to build partnerships between governments and all segments of the civil society, in particular, women, youth, media, and the private sector in order to fight the scourge of corruption ..." Likewise, the United Nations Convention states in its preamble that: "[b]earing in mind that the prevention and eradication of corruption is a responsibility of all States and that they must cooperate with one another, with the support and involvement of individuals and groups outside the public sector, such as civil society, non-governmental organizations and community-based organizations, if their efforts in this area are to be effective...”.

For the United Nations, the Convention against corruption is the culmination of the work that started many years ago, when the word 'corruption' was hardly ever uttered in official circles. It took systematic efforts, first at the technical, and then gradually at the political level to put the fight against corruption on the global agenda ${ }^{49}$ Furthermore, the Convention recognizes the political causes but also the political consequences of corruption. It acknowledges the political threats that corruption may cause namely to fragile States. Even for the signing of the UN Convention, a political consensus of UN member States was atypically needed which was done at a "Political Signing Conference". As educed in the Preamble of the UN Convention where the UN General Assembly recalls the United Nations Convention against Corruption was open[ed] for signature at the High-level Political Signing Conference [... held in Merida, Mexico, from 9 to 11 December 2003, in accordance with resolution 57/169." ${ }^{50}$

On the same note, both the United Nations and African Union Conventions address corruption at the political level, recognizing the importance of the empowerment of political

68 See article 3 of the Convention.

49 Preamble of the UN Convention. ${ }^{71}$, article 9 of the AU anti-corruption Convention.

50 Preamble of the UN Convention against corruption paragraph numbered 2 . 
entities such as the civil society and media in the fight against corruption. This is important as beyond the criminalisation, the UN and AU Anti-Corruption Conventions typically focus on preventive measures. For instance, the AU Convention obliges State parties to ensure the right of access to any information that may be required to assist in the fight against corruption. ${ }^{66}$ It further obliges State parties [to] agree to consult and seek the full participation of the media in the implementation of the Convention and to create an enabling environment that will enable the media and other civil society organizations to hold governments to the highest levels of transparency and accountability in the management of public affairs, for example by giving them access to information in cases of corruption. ${ }^{51}$

In the same vein, these measures include transparency in the funding of political parties as well as the proscription of the use of funds acquired through illegal practices in the fight against corruption..$^{52}$ According to these legal instruments, each State Party are to "consider taking appropriate legislative and administrative measures, [...] with the fundamental principles of its domestic law, to enhance transparency in the funding of candidatures for elected public office and, where applicable, the funding of political parties. ${ }^{53}$

Yet, the ways and means defined by the World Bank guidelines are clearly not to allow the Bank to take political factors into account in dealing with corruption. This political prohibition also sets disparities in anti-corruption efforts, different standards than those set by the anti-corruption legal instruments that create binding obligations on African States.

\subsection{Anti-corruption sanctions of the World Bank and the AU-UN Conventions}

The legal implications of the political prohibition clause of the World Bank can also be seen at the level of the sanctions for corruption. Both the UN and AU Conventions oblige State

51 See article art 12(1) (2) (3) (4) of the AU Convention

52 See article 10 of the AU Convention

53 See article 7(3) of the UN Convention 
parties to take sanctions against corruption such as confiscation ${ }^{54}$ or direct recovery of property. ${ }^{55}$

Rather, the Bank Guidelines, shaped with the influence of the political prohibition, does not provide for a possibility of intervention of the Bank in case of corruption. The Guidelines rather indicate that Bank may or may not intervene in case of Fraud and Corruption that could occur in connection with the preparation and implementation of programs financed, in whole or in part, by IBRD or IDA through Program forResults Financing. The Guidelines state that: "[i]n furtherance of the above-stated purpose and general principles, except as otherwise agreed in writing by the Borrower and the Bank, the Bank: a- Promptly informs the Borrower of all credible and material allegations or other indications of Fraud and Corruption in connection with the Program that come to its attention, consistent with Bank policies and procedures; $b$ - In cases where the Bank determines it necessary to do so to fulfil its fiduciary duty, may conduct an inquiry into such allegations or other indications, independently of or in collaboration with the Borrower; [...] (d) May sanction ${ }^{56}$ any individual or entity other than the Member Country ${ }^{57}$ if at any

54 The AU Convention defines confiscation as 'any penalty or measure resulting in the deprivation of property, proceeds or instrumentalities ordered by a court of law following proceedings in relation to a criminal offence or offences connected with or related to corruption".

55 The UN Convention compels States parties to "take such measures as may be necessary to permit another State Party to initiate civil action in its courts to establish title to or ownership of property acquired through the commission of an offence established in accordance with this Convention; (b) Take such measures as may be necessary to permit its courts to order those who have committed offences established in accordance with this Convention to pay compensation or damages to another State Party that has been harmed by such offences".

56 Sanctions include (but are not limited to) publicly declaring such individual or entity ineligible, either indefinitely or for a stated period of time, to: (i) be awarded a Bank-financed contract; (ii) benefit from a Bankfinanced contract, financially or otherwise, for example as a subcontractor; and (iii) otherwise participate in the preparation or implementation of the Program or any other project or program financed, in whole or in part, by the Bank. The Bank may publish the identity of any individual or entity sanctioned under subparagraph 7 (d).

57 For purposes of these Guidelines, "Member Country" includes (i) officials and employees of the national government or of any of its poli-tical 
time the Bank determines that such individual or entity has engaged in fraud and corruption in connection with the Program or any other Bank-financed activity or is otherwise subject to sanction pursuant to its prevailing policies and procedures" ${ }^{58}$

This provision shows a non-political approach to sanctioning corruption by the Bank. The Bank's approach to sanctioning corruption is predetermined by a condition: 'if at any time the Bank determines that such individual or entity has engaged in fraud and corruption in connection with the Program or any other Bank-financed activity'. This precondition even if met, is not binding on the Bank to act promptly by sanctioning the individual or entity responsible. Furthermore, the Guidelines say the Bank 'may' sanction meaning the Bank 'may not' as well.

In the same line, the Bank Guidelines state that the Bank 'may sanction' only individual or entity other than the 'Member Country'. The Guidelines specifies that 'Member Country' that is excluded from the scope of the Bank sanctions includes '(i) officials and employees of the national government or of any of its political or administrative subdivisions, and (ii) non-autonomous government-owned enterprises. ${ }^{80}$

This provision is not in line with either the AU or the UN Anti-corruption Conventions. The two conventions set obligations to Member States to sanction corruption including against corrupt public officials. The Bank's principle of excluding 'public officials' from the scope of the sanctions for corruption is not in line with the principles and procedures set by both the AU and UN Conventions. 'Public officials'59

or administrative subdivisions, and (ii) non-autonomous government owned enterprises.

58 See World Bank Guidelines on preventing and combating fraud and corruption in program for results-financing, paragraph 7

59 Following the UN anti-corruption Convention for example, "Public offi -cial" shall mean: (i) any person holding a legislative, executive, administrative or judicial office of a State Party, whether appointed or elected, whether permanent or temporary, whether paid or unpaid, irrespective of that person's seniority; (ii) any other person who performs a public function, including for a public agency or public enterprise, or provides a public service, as defined in the domestic law of the State Party and as applied in the pertinent area of law of that State Party; (iii) any other person defined as a "public official" in the domestic law of a State Party. 
including foreign public officials ${ }^{60}$ are targeted by the UN and AU Conventions and should be sanctioned in any case of corruption. Article 15 of the UN anti-corruption Convention for instance states ad litteram that: '[e]ach State Party shall adopt such legislative and other measures as may be necessary to establish as criminal offences, when committed intentionally:

(a) the promise, offering or giving, to a public official, directly or indirectly, of an undue advantage, for the official himself or herself or another person or entity, in order that the official act or refrain from acting in the exercise of his or her official duties;

(b) the solicitation or acceptance by a public official, directly or indirectly, of an undue advantage, for the official himself or herself or another person or entity, in order that the official act or refrain from acting in the exercise of his or her official duties'.

Finally, the Bank's anti-corruption Guidelines as drafted have conflicting provisions with the binding obligations on AU and UN member States to prevent and fight against corruption as defined by the AU and UN anti-corruption Conventions. These conflicting provisions have to be considered by the Bank, as the current cognitive and normative trends in International Development Law are to clearly define and set the nature and legal obligations of IFIs toespect, protect and fulfil international human rights.

The UN Human Rights Council in its Resolution $\mathrm{A} / \mathrm{HRC} / \mathrm{RES} / 34 / 3$ recognised on one hand that "marginalized groups are at particular risk of suffering from the adverse impact of corruption on the enjoyment of human rights and on the other hand, highlighted that States shall [...] endeavour to establish and promote effective practices aimed

However, for the purpose of some specific measures conta -ined in chapter II of this Convention, "public official" may mean any person who performs a public function or provides a public service as defined in the domestic law of the State Party and as applied in the pertinent area of law of that State Party.

60 Following the UN anti-corruption Convention, "Foreign public official" shall mean any person holding a legislative, executive, administrative or judicial office of a foreign country, whether appointed or elected; and any person exercising a public function for a foreign country, including for a public agency or public enterprise. 
at the prevention of corruption and its impact on the enjoyment of human rights, and to periodically evaluate relevant legal instruments and administrative measures with a view to determining their adequacy to prevent and fight corruption, including by ensuring transparency, access to public information, accountability, non-discrimination, and meaningful participation in the conduct of public affairs" ${ }^{61}$ The HRC in the same resolution, equally welcomed the 2030 Agenda for Sustainable Development including its recognition of the need to build peaceful, just, and inclusive societies that provide equal access to justice and that are based on respect for human rights, on effective rule of law, and on good governance at all levels, as well as on transparent, effective, and accountable institutions, and its addressing of factors that give rise to violence, insecurity, and injustice, such as inequality, corruption, poor governance, and illicit financial and arms flows.

\section{ADDRESSING THE NEGATIVE EFFECTS OF THE ARTICLE 4(10) OF THE BANK CHARTER}

Considering the above-identified legal issues related to the prohibition clause of the Articles of Agreements, there are multiple solutions or possibilities to address the problems raised. The World Bank can either amend its Articles of Agreement or interpret it in a more progressive way or teleological manner that would encompass all the existing conventional standards related namely in the international safeguard of human rights and mechanisms to fight corruption.

As far as the Article 4(10) per se is concerned, this article provides two possible solutions or proposals with respect to addressing article 4(10) of the Bank Charter. The proposed solutions aim at allowing the Bank to better engage into corruption and human rights or related issues, which given their potential political nature, fall within the scope of the political prohibition clause. The proposed solutions are namely: the amendment of the Bank Articles of Agreement on one hand and the adoption of a teleological interpretation of the Articles of Agreement, which will allow the Bank

61 https://undocs.org/A/HRC/RES/35/25 (accessed 20/10/2019). 
Executive Directors to adjust, regulate, fine-tune, correct and change the Bank policies in favour of issues that were excluded from its scope such as human rights and corruption. This is a necessary step to enable the World Bank to continue or better co-exist in a global economic and socio-political changing environment guided by sustainable development principles and goals based on a culture of human rights realisation and enjoyment by all.

For the first proposed solution, the amendment of the Bank's Charter, it is important to note that it is complex and to be challenging. The amendment procedure within the Bank is very strict and its members have rarely resorted to this option. The process of amending central provisions of the Bank's Articles of Agreement might be accompanied by attempts by shareholders to introduce other amendments and reshape the Bank's mandate..$^{62}$ The amendment procedure is defined by articles VIII of the IBRD Charter and VII of IDA Charter. It poses a precondition and sets a strict requirement to that effect. Article VIII of the IBRD Charter states that:

"[a]ny proposal to introduce modifications in this Agreement, whether emanating from a member, a governor or the Executive Directors, shall be communicated to the Chairman of the Board of Governors who shall bring the proposal before the Board. If the proposed amendment is approved by the Board the Bank shall, by circular letter or telegram, ask all members whether they accept the proposed amendment. When threefifths of the members, having eighty-five percent (1) of the total voting power, have accepted the proposed amendments, the Bank shall certify the fact by formal communication addressed to the members."

Clearly to be amended, the IBRD Articles of Agreement has to be approved by the Board of Governors and be accepted by 60 per cent of IBRD members holding 80 per cent of the total voting power. As pointed out by Cisse, "considering that the political prohibition clause touches on an issue on which little consensus seems to exist among member countries, it is

${ }_{62}$ Hassan Cisse, (n 1 above), (22). 
doubtful whether sufficient votes could be mustered to effect the requisite amendment". ${ }^{63}$ This restrictive process has only permitted the IBRD Articles of Agreement to be revised twice while the IDA Charter remains unchanged. ${ }^{64}$

The second suggested solution is a teleological interpretation of article 4(10) of the Bank Charter in line with Article 31 of the Vienna Convention on the Law of Treaties. Nevertheless, the challenge to face is that when interpreting the Articles of Agreement, the Bank Executive Directors are not expected to act as a court of law. However, this does not mean that the Executive Directors may interpret the Articles of Agreement without any legal or policy constraints. Rather, they must interpret the Articles in accordance with principles of treaty interpretation and applicable policy requirements. ${ }^{65}$

In particular, they must consider the requirements of effectiveness, reasonableness, good faith, and the Bank's common interests and those of its members. In addition, in making a formal interpretation, the Board usually has the benefit of legal opinion on the subject from the General Counsel in interpreting its Articles, the Bank has generally adopted a teleological or purposeful interpretation. This technique has been followed because the Bank, as a multilateral institution, must nimbly respond to the changing needs of its members and the evolving concept of development itself. ${ }^{66}$ Hence, this technique is most suitable for international organizations since it enables them to adapt to a rapidly changing world. By relying on this technique, the Bank would continue to be able to overcome certain textual anachronisms in its Articles that were no longer serving the institution's objective. ${ }^{67}$ Moreover, through this process, Executive Directors may fill acknowledged gaps in the Articles to enable

${ }_{63}$ Hassan Cisse, (n 1 above), (83).

${ }^{64}$ Hassan Cisse, (n 1 above), (83).

65 Vice President and General Counsel, "Interpretation" and the "Exercise of Implied Powers" in Respect of the Bank's Standard Value (May 7, 1985) at paragraph 4.

66 Andres Rigo Sureda, 'The Law Applicable to the Activities of Internation -al Development Banks', (308) Recueil Des Cours 9, 157 (2004), see also, Henry G. Schermers \& Niels M. Blokker, 'International Institutional Law: Unity within diversity' 832-835 (844).

${ }^{67}$ Ibrahim Shihata, 'World Bank Legal Papers' xxxix (2000) at lx. 
the institution to fully pursue its objectives. ${ }^{68}$ At the same time, neither teleological interpretation nor any other technique can be abused to render illogical constructions of the written text. A Board interpretation, which seeks to amend the Articles or radically reshape the Bank's institutional structure, is an unauthorized amendment that cannot pass legal muster. ${ }^{69}$ On this line, changes through interpretation, rather than amendment, cannot affect the fundamental features of an international organization's charter.

This is perhaps the process that has led the World Bank to initiate the Stolen Asset Recovery since 2007 based on a proactive appreciation of the scourge of corruption. The Stolen Asset Recovery is a joint initiative between the Bank and the United Nations Office on Drugs and Crime (UNODC). Set up in 2007, the Stolen Asset Recovery (StAR) Initiative focuses on helping developing countries recover assets stolen by corrupt officials and hidden in foreign countries. The StAR is a result of the proactive involvement in governance and anti-corruption by the World Bank from the early 1990s. As noted by Cisse, the Asset recovery often takes place in the context of a change of governments. This is just an exemplary initiative that shows the Bank can do much more to address the issue by preventing, detecting, punishing and eradicating corruption and related offences meeting hereby the same standards of both the AU and UN anti-corruption conventions.

\section{CONCLUSION}

The above analysis shows that mending the existing mechanisms to address anti-corruption policies and mechanisms of International Financial Institutions in general and the World Bank Group in particular has been beneficial in improving governance practices. In the Foreword to the UN Convention against Corruption, former UN Secretary General, Kofi Atta Annan wrote that 'corruption is an

68 Vice President and General Counsel, "Interpretation" and the "Exercise of Implied Powers” in Respect of the Bank's Standard Value (May 7, 1985) at paragraph 4.

69 IAD, 'Terms of Reference' [2005] and Senior Vice President and Group General Counsel, Legal Memorandum on Board Involvement in Senior Appointments, COGAM2007-0016 and PC2007-0014 (June 6, 2007), at paragraph 4. 
insidious plague that has a wide range of corrosive effects on societies. ${ }^{70}$ The World Bank Group considers corruption a major challenge to its twin goals of ending extreme poverty by 2030 and boosting shared prosperity for the poorest 40 per cent of people in developing countries. Yet corruption continues to hamper the efforts to meet the goals of ending extreme poverty and boosting shared prosperity.

The Report of the African Union High Level Panel on Illicit Financial Flows from Africa, chaired by H.E Thabo Mbeki, former President of South Africa, in partnership with the United Nations Economic Commission revealed that Africa loses about 50 billion US dollars annually due to that. ${ }^{71}$ Corruption has had a corrosive effect on Africa's development: it has weakened public institutions, distorted resource allocation, and affected the quality and scope of the delivery of social services.

The African Union Agenda 2063, under Aspiration 3 recognizes that corruption erodes the development of a universal culture of good governance, democratic values, gender equality, and respect for human rights, justice and the rule of law. The United Nations 2030 Agenda for Sustainable Development Goals, under Goal 16, calls on all countries to promote and develop accountable and inclusive institutions at all levels, notably, by reducing bribery and corruption. It is therefore important for International Financial Institutions such as the World Bank to align its procedures to the current global and regional anti-corruption standards.

Following the African and UN anti-corruption Conventions, fighting corruption efficiently should include active and broad-based stakeholder engagement. The World Bank should invest more of its anti-corruption strategies in empowering citizens. It should also strengthen its new Expert Advisory Council on Citizen Engagement. The Bank's increased collaboration with citizens in decision-making processes can make its decisions more responsive to citizens' needs and improve the sustainability of program and project outcomes through increased ownership by citizens.

70 Foreword to the UN Convention against Corruption https://www.un odc.org/documents/brussels/UN_Convention_Against_Corruption.pdf

71 UNECA, Illicit Financial Flow: Report of the High Level Panel on Illicit Financial Flows from Africa https://www.uneca.org/sites/default /files/PublicationFiles/iff_main_report_26feb_en.pdf 